"This is an Accepted Manuscript of an article published by Taylor \& Francis in [Early Child Development and Care on [13 Mar 2017], available online: http://www.tandfonline.com/[10.1080/03004430.2017.1289926 ].”

Zsuzsa Millei and Jannelle Gallagher Ad-hoc numbers forming provision and policy: round and round of universal access in an Australian preschool Early Child Development and Care http://dx.doi.org/10.1080/03004430.2017.1289926

\title{
Ad-hoc numbers forming provision and policy: Round and round of universal access in an Australian preschool
}

\section{Introduction}

Worldwide, current ECEC policy making and evaluation are increasingly evidence and data based (Roberts-Holmes \& Bradbury, 2016; Campbell-Barr \& Nygård, 2014; Millei, 2016; Osgood, 2009). It is fuelled with a growing belief in and reliance on new types of knowledge and insights produced through these means (Grek \& Ozga, 2010). In this international context, the imperative to produce 'good' data is often asserted by national governments in a similar manner to the 2016 Australian Productivity Commission's inquiry into the National Education Evidence Base':

Having comprehensive and consistent data that underpins a national evidence base will inform education policy and help improve educational outcomes for children. ... Valuable data is also collected outside schools, including in early childhood education and care. Improved access and greater ability to link and analyse national data could enhance the quality and scope of national education evidence that can be used to monitor educational outcomes and inform policy development and evaluation (Productivity Commission, 2016, p.iii).

Policy making informed and evaluated by quantified measurements and evidence contributes to the process of what Grek \& Ozga (2010, p. 272) terms as the 'scientization' of education governance, where it is “increasingly assumed that it is only knowledge based on data (and in particular statistical knowledge) that can reveal problems and shape solutions". Of particular significance in this process is the role of numbers and trust invested in them (Porter, 1995). Trust in numbers is premised on a view of their objectivity and their assumed capacity to characterise reality. Numbers in policy documents and business plans are also used as temporary or conditional devices to enable rationalization, to bring into motion activities that are themselves conditional and ephemeral (Lampland, 2010)

The scientization of education governance lends objectivity to policy making and makes governments' decisions seem impartial or apolitical (Porter, 1995). However, politics is not absent from policy making and there is also a paradox in the scientization of education governance that opens other avenues for politics. This paradox is that the

\footnotetext{
${ }^{1}$ http://www.pc.gov.au/inquiries/current/education-evidence\#draft
} 
Zsuzsa Millei and Jannelle Gallagher Ad-hoc numbers forming provision and policy: round and round of universal access in an Australian preschool Early Child Development and Care http://dx.doi.org/10.1080/03004430.2017.1289926

production of 'objective data' relies on professionals. Data produced by them inform and more recently have the capacity to move policy (Grek \& Ozga, 2010). At the same time professionals' work is assessed based on evidence, measurements and policy they themselves produce (Roberts-Holmes \& Bradbury, 2016; Campbell-Barr \& Nygård, 2014; Grek \& Ozga, 2010). This paradox places professionals in an ambivalent position with data production that both controls their work and opens new possibilities, for example, in advocacy work and activism in regards to policy.

In Australian early childhood education and care (ECEC), the need for and problems with data production came to the fore at the time when the federal government made its decision to get involved in $\mathrm{ECEC}^{2}$, which last took effect during the 1970s. The intent was to provide quality ECEC and universal access to it, together with thorough data and evidence production for policy making. Some of the reasons for the lack of comprehensive and consistent data in ECEC, as Dowling and O’Malley (2009, p. 2) explain, is that ECEC "data as a whole in Australia have been described as confusing, with the sector containing a serious lack of national comparability and having 'orders of magnitude' more complex than schooling ... However, the persistence of data problems also stems from the fact that Australian investment in ECE has, in the past, been abysmally low". Overall, the system has lacked, and is still in the process of developing, those processes that enable the quantification, reporting and modelling of issues with workforce, quality standards, enrolment patterns, and the modernisation of infrastructure.

The path towards universal access to ECEC in Australia started with an intergovernmental agreement, the National Partnership Agreement on Early Childhood Education in $2008^{3}$ (National Partnership from hereafter), which followed international frames developed by large international organizations (such as Education For All ECEC

\footnotetext{
2 The Australian Government's roles and responsibilities for ECEC include: paying Child Care Benefit (CCB) to eligible families using approved child care services or registered carers, paying Child Care Rebate (CCR) to eligible families using approved child care services, providing funding to State and Territory governments through the National Partnership (centre based funding). Agreement on Universal Access to Early Childhood Education (NPUAECE) to support the achievement of universal access to early childhood education from http://www.pc.gov.au/research/ongoing/report-on-governmentservices/2015/childcare-education-and-training/early-childhood-education-and-care/rogs-2015-volumebchapter3.pdf

$\overline{3}$ http://ccccnsw.org.au/wp-content/uploads/national_partnership_on_early_childhood_education.pdf
} 
Zsuzsa Millei and Jannelle Gallagher Ad-hoc numbers forming provision and policy: round and round of universal access in an Australian preschool Early Child Development and Care http://dx.doi.org/10.1080/03004430.2017.1289926

global initiatives or OECD frames) about countries' obligations to deliver universal ECEC (Millei \& Jones, 2014). This obligation was reasoned with female workforce participation, children's rights to early education that ensures learning outcomes and economic rationales (White, 2011). The National Partnership agreement justified this renewed national effort by the growing international scientific evidence base for the importance of early learning produced in brain research and the economic benefits of early childhood evidenced by Heckman and colleagues (Millei \& Joronen, 2016; Millei, 2015).

Universal access necessitated the creation of systemic processes of quantification and reporting and professionals' involvement to produce reliable and quality data for policy making and evaluation. Techniques of quantification and formal representation (e.g. graphic formulae or charts) became instrumental in creating standards and gauging processes to facilitate the production of data on ECEC. With the biographical notes of a preschool director, the second author of this paper, we attend to the procedures whereby new practices of quantification, rationalisation and reporting are being introduced and mastered in a New South Wales preschool. We are particularly interested in the roles number play within these. We see 'provisional numbers' (Lampland, 2010) as instrumental in configuring and solidifying activities and processes that exist in temporary or conditional forms in current practices. Thus, we aim to historically document the formalization of processes and practices that often rub against or entangle with others that concurrently take place. We explore the ambivalent positions professionals find themselves in, the ethical dilemmas that emerge, and the practical and material consequences that formalizing processes of data production in ECEC bring in a preschool. We believe that focusing on the ways in which international initiatives, such as universal access, criss-cross and shape everyday actors' work, is highly useful in understanding, unsettling and debating them. In the spaces produced, new forms of politics might take shape that progresses visions that the Australian, and international, ECEC sector has long been striving for (Bown \& Sumsion, 2016; Macfarlaine \& Lewis, 2012). 
Zsuzsa Millei and Jannelle Gallagher Ad-hoc numbers forming provision and policy: round and round of universal access in an Australian preschool Early Child Development and Care http://dx.doi.org/10.1080/03004430.2017.1289926

\section{Universal access to ECEC in Australia}

It was the 29 November 2008 when the Council of Australian Governments ${ }^{4}$ (CoAG) signed the National Partnership aiming to ensure universal access to quality ECEC by 2013. Universal access means securing accessibility to early education program for 15 hours per week for 40 weeks per year to all children before they enter school ( 4 and 5 years olds) in Australia. The education program forming the curricular part of universal access must be delivered by a 4-year university trained teacher to ensure quality. The 15 hours of provision must be affordable for families, meaning that it must be ensured that there will be no increase in fees paid by families. CoAG also set out to grow vulnerable and Indigenous children's enrolment drawing on the evidence that their inclusion into ECEC brings the largest benefits for the economy.

As OECD data from $2014^{5}$ show, universal access has not been achieved by 2013 . Internationally 3-year old enrolments lag behind greatly and 4-year old enrolments are also located towards the end of the international league table. In August 2014, a national review ${ }^{6}$ took place reporting that in most states children's enrolments have reached almost $100 \%$ and came very close to reaching the target universal access hours. The situation was and still is different in New South Wales (NSW) where only $82 \%^{7}$ of 4 year old children were enrolled into these provisions in 2013 and out of those only 59\% were enrolled to the mandated hours of 600 hours per year. Since universal access has not been reached nationally by the end of 2013 as targeted, and where it was it still needs to be maintained, the National Partnership has been extended to the end of 2015 in $2014^{8}$ and then in January $2016^{9}$ to June 2018.

The NSW case offers a good example to gain a glimpse of ongoing formalizations of

\footnotetext{
${ }^{4} \mathrm{CoAG}$ is the peak intergovernmental forum in Australia composed of the Prime Minister, State and Territory Premiers, and Chief Ministers and the President of the Australian Local Government Association. CoAG is charged with implementing reforms.

${ }^{5}$ https://www.oecd.org/els/soc/PF3_2_Enrolment_childcare_preschool.pdf

6 http://www.scseec.edu.au/site/DefaultSite/filesystem/documents/Reports $\% 20$ and $\% 20$ publications/EC \%20Publications/NP_UAECE\%20Review-220415.pdf

7http://www.scseec.edu.au/site/DefaultSite/filesystem/documents/Reports\%20and\%20publications/EC \%20Publications/NP_UAECE\%20Review-220415.pdf

8 http:/ /www.abc.net.au/news/2014-09-05/federal-government-to-commit-millions-to-preschoolextension/5722836

${ }^{9}$ http://www.federalfinancialrelations.gov.au/content/npa/education/nationalpartnership/2016_2017_universal_access_NP.pdf
} 
Zsuzsa Millei and Jannelle Gallagher Ad-hoc numbers forming provision and policy: round and round of universal access in an Australian preschool Early Child Development and Care http://dx.doi.org/10.1080/03004430.2017.1289926

processes and practices through which new places are created, enrolments are increased and data is being produced to achieve universal access. In NSW, the delivery of early childhood education programs are dominantly handled by community preschools ${ }^{10}$. Taking the case of a particular NSW preschool, and the director's stories about ongoing negotiations provide a unique access into formalizing processes in preschools. Attending merely to the features of formalized procedures (implemented policy initiatives as rules and regulations) overlooks the dynamic social processes by which rationalization actually occurs (Lampland, 2010). Taking a personal perspective is also helpful in highlighting how rationalization takes place, the investments local actors make, the different pulls, power relations and ethical considerations that it includes but which often remain invisible or become sanitized in formalized institutional processes and practices.

\section{Methodological notes}

In the following stories on universal access, we use national and NSW policy documents together with biographical notes of the preschool director. From these stories professionals, parents' points of views and state bureaucrats' engagements with her also emerge. These biographical notes recount events occurred as different policy initiatives were released and related discussions occurred with colleagues, members of the preschool's Management Committee, families and policy-makers. In our analysis, biographical notes do not represent reality rather provide the director and others' perspectives as they were told and being retold.

Following Mills' (1959, p. 226) sociological imagination, our exploration of universal access "include both troubles and issues, both biography and history, and the range of their intricate relations". Using biography becomes research if "shown to have relationship to and bearing on the context and ethos of a time" (Bullough \& Pinnegar, 2001, p. 15). Jannelle's stories tell about how the formalization of conditional, ephemeral and new processes recreated the spaces - both imagined and real - in her preschool that

\footnotetext{
${ }^{10}$ Community preschools are mostly community owned, based and managed. They are mostly not for profit centres and have two types: 1 , stand alone preschool managed by a committee comprised of parents and community members; and 2, sponsored where an organisation is managing the preschool, sometimes with advisory committees comprised of parents and community members. In NSW some preschools are operated by the Department of Education. Long Day Care services also offer early childhood program but enrolments of children in that are very low as the figure shows. http://www.preschoolsnsw.org.au/aboutpreschools/community-owned
} 
Zsuzsa Millei and Jannelle Gallagher Ad-hoc numbers forming provision and policy: round and round of universal access in an Australian preschool Early Child Development and Care http://dx.doi.org/10.1080/03004430.2017.1289926

helped to come one step further to universal access, the creation of its measurements and data production on its achievement. However, her stories also shed some light on the ambivalent positions she and her colleagues have found themselves in and their feelings about those. Her biographical notes intend to "provoke, challenge, and illuminate rather than confirm and settle” (Bullough \& Pinnegar, 2001, p. 20).

While there is a growing importance of narratives in education research generally, autobiography has seldom found a place in policy analysis (see for exemption Warren, 2017). In autobiographical research, past, present and future and the voice of the researcher and narrator become entangled where past life of the narrator / researcher is rearranged retrospectively, and reinterpreted in terms of the meaning that she may intend to present in research with the aim to effect future change. In biographical notes, scenes and situations connect with others' actions and provoke intense reflections from readers (Bullough \& Pinnegar, 2001). In the following sections after introducing the policy context, we include the biographical notes of the director (as 'data' and printed in italics) and contextualise those with concurrent policy developments. Then we apply some concepts for the analysis of 'data' and policy texts, such as provisional numbers, scientization of governance and so on, to explore and describe the processes taking place and the roles policy and preschool actors play in those.

\section{Provisional numbers in universal access}

After the release of National Partnership and universal access in 2009, most individual ECEC settings, such as long day care centres, work based day care centres or community preschools, had to modify the structure of their provisions. To provide 15 hours per week (later 600 hours per year) early learning program for children, necessitated large restructurings in the hours of provision, staffing and budgeting. Commonwealth funding delivered to states for distribution intended to fund new places, salaries, training and restructuring.

In the case study preschool where 3 and 4 years old children are enrolled between the hours of 9 am to $3 \mathrm{pm}$, the situation looked the following way. Many children attended 2 full days coming either on Monday and Tuesday, or Thursday and Friday and those who came for three days also attended Wednesday. This allowed for the groups to have stable 
Zsuzsa Millei and Jannelle Gallagher Ad-hoc numbers forming provision and policy: round and round of universal access in an Australian preschool Early Child Development and Care http://dx.doi.org/10.1080/03004430.2017.1289926

participants with the same educators (a requirement for high quality provision) and 12 hours preschool education per week for many children. In order to allow for children to become enrolled for 15 hours per week required that the preschool raises the number of hours provided per day to 7 and a half hours. This would have meant extra operational hours and changes in staff's employment pattern with consequences on the preschool budget.

In NSW preschools are managed by a Management Committee composed of community members, parents and teachers. There is also a director who oversees the operation of the preschool, including pedagogical, human resource and financial areas. The preschool operates mostly on parental payments (parents receive some subsidies from the federal government but that is income assessed), with some subsidies from the state government, funding gained through enrolling children with special needs or Indigenous children, and fundraising. Educators' salaries compose the largest expenditure in the budget. Keeping fees low for families and providing quality education is a balancing act that requires full enrolment and skilful planning. Changing the pattern of provision would have had a large impact on the viability of the preschool, so carefully crafted and maintained in the past.

Interestingly, the 15 hours requirement for a learning program was never justified by the National Partnership or any other document (Brennan, 2012). It did not fit the existing provision patterns either and had no evidence base. The requirement of 15 hours has shifted the focus on to 4-year olds, children with special needs, and disadvantaged backgrounds and from Indigenous families. It presented considerable challenges for several reasons: 1) changed focus on only 4-year olds disadvantaging 3-year olds' enrolment, 2) change in week provision pattern allowing less children to access preschool education in overall, 3) change in 4 year trained teacher numbers on staff to allow for new pattern of program provision and educators to be rostered in with them, 4) availability of willing families to enrol their children for 15 hours since it meant increased weekly fees and changed attendance patterns, 5) focus on enrolment of children whose education required special professional knowledge and staff, 6) changes in budget due to increased payment for teachers (compared to educators paid at lower salaries) and extra professional staff and 7) decreased subsidies for 3-year olds. Besides these structural and financial issues, preschools also had to come to terms with new initiatives, terminologies, 
Zsuzsa Millei and Jannelle Gallagher Ad-hoc numbers forming provision and policy: round and round of universal access in an Australian preschool Early Child Development and Care http://dx.doi.org/10.1080/03004430.2017.1289926

IT systems, reporting routines and make difficult calculations based on highly complex policy initiatives to balance their budgets and to increase enrolments.

We asked ourselves 'why 15' and how can this number, no matter how arbitrary or provisional it is, ignite so many large scale changes? We have found the concept of 'provisional number' used by Lampland (2010) helpful in understanding the seemingly ad-hoc number of '15 hours per week' that has set the path toward universal access and the role this number had and continue having, although in a changed form (600 hours in a year), in reorganising institutional practices in preschools. Later on this number was joined by others, setting 'prices' for different children's enrolment. Provisional numbers are special numbers. They are not referents to stable entities carrying the same meaning in each context. They are not meaningful in other contexts and appear in specific situations, such as planning and strategizing, in our case in creating strategies and models to reach universal access. Provisional numbers are instrumental in setting off modelling, they aid "in setting the parameters for tasks at hand and debating their relative merit. In other instances, provisional numbers parade as stable and fixed indicators, though their provisional status is well known by those responsible for making them" (Lampland, 2010, p. 378).

The number of ' 15 hours' presented a considerable challenge to preschools and set in motion large efforts to reorganize the provision of the early learning program through iterative modelling processes that have been repeatedly reformulated over time. Simplifying conditions and granting unrealistic assumptions are necessarily part and parcel of these modelling processes through which the model gains its contours and configurations and provide a solution. In NSW '15 hours' did not lead to a viable model of provision alone and therefore, new numbers were introduced, in financial terms and attached to children's enrolment.

Following the Review of NSW Government Funding for Early Childhood Education (Review) (commissioned by the Minister for Education, the Hon Adrian Piccoli MP, and delivered by Prof Brennan (2012)), in 2013, preschool directors and parent management committees in NSW were advised that a new funding model would replace the existing Resource Allocation Model (RAM) and the 15 hours requirement per week was also changed to 600 hours in a year. The Review's aim was to develop funding strategies that 
Zsuzsa Millei and Jannelle Gallagher Ad-hoc numbers forming provision and policy: round and round of universal access in an Australian preschool Early Child Development and Care http://dx.doi.org/10.1080/03004430.2017.1289926

helps the state to fulfil universal access. This policy initiative has been decided on the evidence provided by the Review that "community preschools make a significant contribution to the overall participation rate but around one-third of the children attending these preschools (more than 15,000 children) are not in their year prior to school. Most of these children are not in the equity target groups discussed in the Review” (Brennan, 2012, p. 20).

RAM sought to offer equitable distribution of funds to all families. The new funding model intended to give financial incentives to preschools to enrol 'equity target group' children before the year of schooling in order to reach universal access. The Report highlighted the difficulties associated reaching this goal in a context where ECEC has suffered for several decades from extremely low investment and the complexities of mixed market provisioning. It concluded that current funding programs were poorly targeted and not directed at NSW strategic priorities for early childhood education. The reasons listed in the Review were the following (p. 1):

- NSW has the highest preschool fees in Australia;

- in some parts of the State there are not enough suitable places ('suitability' requires services to be affordable and accessible, to demonstrate cultural respect and acceptance and to operate at times that meet families' needs); and

- some children are not receiving an early childhood education program even though they are attending an early childhood service.

Following some of the recommendations of the Brennan Review, a new initiative was born dominated by provisional numbers as incentives attached to children's enrolment, and is titled the Preschool Funding Model (PFM see Figure 2.) 
Zsuzsa Millei and Jannelle Gallagher Ad-hoc numbers forming provision and policy: round and round of universal access in an Australian preschool Early Child Development and Care

\section{How does the model work?} AT A GLANCE

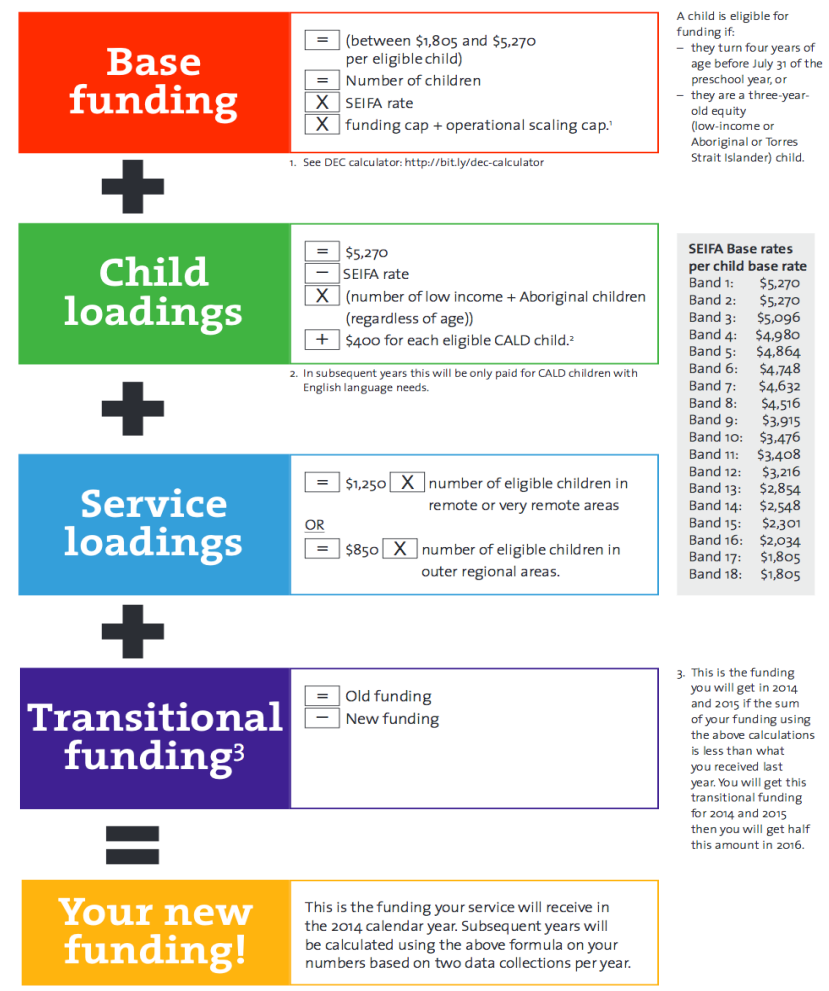

Figure 1. Schematic view of PMF by Community Childcare briefing paper http://ccccnsw.org.au/wp-content/uploads/broadsidebriefing_2013-07.pdf

Community Child Care Co-operative ${ }^{11}$ gave also some advice to help preschools' new modelling exercises. According to them, preschools can maximize their funding under the new model by ensuring they enrol to their funding cap children who are in the year before school (who will have turned four years of age by 31 July that year) and children who are economically disadvantaged (measured in $\mathrm{SEIFA}^{12}$ ) and/or Aboriginal or Torres Strait Islander in the two years before school. Services should also ensure they are open

\footnotetext{
11 "Community Child Care Co-operative (NSW) is a not-for-profit organisation established in 1978 to promote, support and advocate for quality education and care services. We aim to inform and inspire the education and care services sector, and influence government policy, practices and programs so that children within NSW have access to quality education and care services that meet the needs of their communities." http://ccccnsw.org.au/about-us/who-we-are

12 "Socio-Economic Indexes for Areas (SEIFA) is a product developed by the ABS that ranks areas in Australia according to relative socio-economic advantage and disadvantage. The indexes are based on information from the five-yearly Census" (Australian Bureau of Statistics). Preschool located in disadvantaged areas were represented by SEIFA area code and children with disadvantaged backgrounds as 'equity children'. This kind of coding makes no difference between a child who is really experiencing disadvantage or not but living in the area, and disabling those families who lived in higher SEIFA areas but still requiring assistance to access this extra funding in order to attend preschool.
} 
Zsuzsa Millei and Jannelle Gallagher Ad-hoc numbers forming provision and policy: round and round of universal access in an Australian preschool Early Child Development and Care http://dx.doi.org/10.1080/03004430.2017.1289926

for at least six hours per day and for at least 40 weeks per year. 'Funding cap' is explained by the Department the following way:

Preschools that operate for the standard school session can typically offer for each licensed place 30 hours of preschool access per week ( 6 hours $\times 5$ days $=30$ hours) and 1,200 hours of preschool access a year (30 hours per week x 40 weeks per year $=1,200$ hours). So for every licensed place, a typical preschool can offer two children 15 hours per week of preschool. This is what the funding cap aims to calculate. (NSW Department of Education, PFM Calculator) ${ }^{13}$

Provisional numbers, this way, set the course to formalize processes by enrolling existing and new practices in the creation of new strategies and models in individual preschools to reach universal access.

\section{Contouring universal access}

Committee members and staff attended information sessions funded by the Department of Education and delivered by peak bodies, such as Community Child Care Co-operative. Many directors were angry voiced their concerns on an online egroup about the number of changes which had occurred in NSW. An overall feeling of change fatigue emerged across the sector. However, a sense of urgency prevailed. Together we unpacked the new model at monthly management meetings and informal gatherings. New terminology demanded our attention as well. What was a SEIFA band? How would we know our SEIF A band funding amount? As these terminologies and types of subsidies were unpacked, our understanding has developed. Funding caps' became an important component of the model. It has required us to recalculate operation schedules, enrolments and subsidies under the 15 hour model, such as 2.5 days per week in order to enable the fulfilment of the National Partnership aims.

While we were familiar with the earlier term 'operational scaling cap', we needed to rethink this under this new model and concept of 'funding cap'. This calculation did not consider the traditional 12 hour model under which NSW preschools operated. The complication of this model came in the delivery of 2.5 days, resulting in services reorganizing enrolment patterns to meet these expectations. Some children attended one day per week and families did not wish or could not afford to enrol their children for longer periods. Meanwbile parents of three year olds required 2 days (12 hours) as did parents of 4-5 year olds.

\footnotetext{
13 http://www.dec.nsw.gov.au/what-we-offer/regulation-and-accreditation/early-childhood-educationcare/funding/community-preschool-funding/providers-preschool-funding/providers-calculate-allocations
} 
Zsuzsa Millei and Jannelle Gallagher Ad-hoc numbers forming provision and policy: round and round of universal access in an Australian preschool Early Child Development and Care http://dx.doi.org/10.1080/03004430.2017.1289926

After surveying families, it was apparent that parents wanted to maintain preschool as they knew it. Parents did not wish to have extended hours and certainly viewed the proposition of 2.5 days as an inconvenience and the suggestion of a 5 day fortnight intolerable. To ensure families and children had access to the required high quality education and care, and to meet the requirement of 600 hours, staff would need to be rostered on longer days. Therefore, increasing the wages bill, placing unnecessary burden on an already tight budget. Transitional funding reassured centres by guaranteeing existing funding levels for 2014 and 2015. However, funding was promised to be halved in 2016.

Working to 'funding cap' refers to filling the maximum number of places that have incentives attached to. This, however, attached a value to the enrolment of particular children also shaping views about which children are more worthy or should take priority in enrolment. These numbers and associated values became productive in shaping the budget, formalize practices and views on children and ECEC. Provisional numbers therefore are productive and "are likely to set the rules, schema and frameworks that constrain and contain the social world" and become the rules of the game (Beer, 2015, p. 10) while sidelining other considerations, such as parents' wishes for their children.

In-house conversations with committee members, parents, educators and teachers constructed our understanding of the new funding model. Concerns over non-equity 3 year olds not being included in the funding model dominated these conversations. It was common knowledge that most NSW preschools relied heavily on 3 year olds to ensure full utilization, this was a two-year cycle. Fees for 3 year olds would need to reflect the true cost of running a preschool. Who could afford this? We entered our 2 year cycle where 3 year olds were essential to the viability of the preschool. They were our "life blood" and this model posed a threat to our preschool. Aggressive advertising was orchestrated with volunteers and staff volunteers. While we were obligated to ensure funding was maximized in order to reduce fees it was agreed that 3 year olds would be lost to other centres if they weren't enrolled. We viewed this as a 'collateral damage'. We continued to enrol the targeted children. Affordability was the key to accessibility for all children. Thus, having higher subsidies meant cheaper fees for others too.

We were driven by the belief that if we could make the enrolment patterns to work for everyone, we could all win. Funding boosts from the government was intended to be passed on to families of 4 or 5 years old children in decreased fees (DEC, 2013), translating into affordable services for all families and a preschool budget much less constrained. We wanted to reach the maximum amount of subsidies to use up all the funds provided in case they were taken away. 
Zsuzsa Millei and Jannelle Gallagher Ad-hoc numbers forming provision and policy: round and round of universal access in an Australian preschool Early Child Development and Care http://dx.doi.org/10.1080/03004430.2017.1289926

Working to 'funding cap' and the enrolment of children with incentives ensure the viability of the preschool, basically, its survival. This situation makes preschools precarious as institutions and workplaces. Besides making various calculations also necessitates that the management continuously makes efforts to promote the preschool and its good standing in the community, in other word to make the preschool enterprising. Both the viability of the preschool and the fulfilment of universal access hinge upon preschools to make their budget calculations right, to get to the 'right' model. To optimize the budget, entities are associated with one another and subjected to manipulations and transformations. These calculations are made in a very material sense, how many of what places needs to be filled at what time periods with trained teachers. In the calculative space, as Callon and Muniesa (2005) explain, entities gain new value by calculation and judgement being joined in a continuous game of value assignment and optimization. It seems that the value of 3 year olds sparked renewed debates.

Working to 'funding cap' means that practices of enrolment need to change in order for the budget to be optimal. In a value assignment, those who receive subsidies (incentives) become the most 'worthy' and sought after in financial terms, and children with no incentives, such as 'non-equity' 3 year olds, mean losing money. In this calculative space, it becomes possible to reason against those values that see the preschool as fulfilling working parents' need or children's rights to education. These judgements also effect the culture of the preschool. As Beer (2015) explains, financial data folds back and reconfigures culture. In this way, we can understand numbers as 'active' and productive. Metrics make efficiencies, reveal truths and create new value. Numbers catalyse the recursive and recombinant processes, which then inform how the enrolment is played and consumed, which then finds its way into universal access.

\section{Ethical dilemmas and power plays}

This new model, however, effectively deprived non-equity 3 year olds (that is children who were not disadvantaged or from an Indigenous background) of a funded position in preschools. If centres enrolled children from this non-priority group they would suffer a financial penalty under the new operational scaling component of the model, that is, reduced funding. How could we still make this affordable to families when we were no longer attracting funding for 3 year olds? What will happen to those 3 year olds 
Zsuzsa Millei and Jannelle Gallagher Ad-hoc numbers forming provision and policy: round and round of universal access in an Australian preschool Early Child Development and Care http://dx.doi.org/10.1080/03004430.2017.1289926

who were willing and ready to come to preschool? Even the Brennan Report has highlighted the subsidies provided FOR ALL CHILDREN in NSW as a positive aspect of state funding which was now ending with even a penalty imposed: "Currently NSW is the only state that provides subsidized preschool to children of any age." (Brennan 2012)

While time ticked by, and many models were created, pulled apart, reconstructed and deconstructed, we also experienced lots of other disconcerting feelings. Each time we worked with a "clear" vision and driven by the government's agenda and to maximize our funding to reduce fees, we felt something inkling. These feelings and thoughts became clearer and started to be voiced. How can the interests, thoughts and professionalism of staff play a role in all this modelling exercise? Were the children and families' voices and concerns listened to and acted upon? While the staff are one of the important contributing factors to offering a bigh quality early childhood education program, I was only considering the interests and survival of the preschool. What was the price we needed to pay, if any? What will be the consequences of these calculations and number games for children, families and staff involved? Many sleepless nights mulling through my concerns and concerns of others I have heard gave me the epiphany I needed.

Our work began, numbers were crunched and we "robbed Peter to pay Paul", so to say. Several budgets were prepared with one finally approved. During these discussions we were also painfully aware that we needed to apply for all available funding because if it is not used within the time frame then the government might withdraw it. Fees were slightly higher for 3 year-olds but families valued our service and were prepared to pay the additional cost. From discussions with the committee and as our understanding of the model increased, a motion was put to the committee suggesting a two-year budget gycle to be adopted. This gave us the opportunity to average the funding over the two years and effectively reduce the fluctuations in fees. This proposal was accepted at the next Management Committee meeting.

Traditionally reporting to the Department was paper based. However, a new online system was introduced. The Early Childhood Contract Management System (ECCMS) collected data around enrolment patterns, utilization, demographics, staffing, and qualifications, including children needing additional support that attracted separate funding (SCAN). This also provided the Department with the base line data which it required to record outcomes met for the National Partnership Agreement (COAG 2009). The sector thought this would streamline the process but it was an arduous task with the system often overloading and crashing during the process. But all was well, we always had until the Sunday to submit the required information. The Department might have reasoned when allowing us to submit until Sunday that preschool staff work anyways around the clock. 
Zsuzsa Millei and Jannelle Gallagher Ad-hoc numbers forming provision and policy: round and round of universal access in an Australian preschool Early Child Development and Care http://dx.doi.org/10.1080/03004430.2017.1289926

Information gathered through the online system was reflected in our level of funding the following year. Thus, funding based on the previous year's figure, not on the current cohort impacted seriously on the delivery of the program. The funding was not reflective or responsive to the 'bere and now' potentially resulted in children not receiving the allocated funding in their year of attendance. For example, centre management had to act prudently with previous funding allocations through investments so to ensure that additional support educators could potentially be employed even if the child haven't been counted and therefore funded.

As predicted our funding was substantially cut. We had suffered a $\$ 32,000$ cut due to our enrolment of non-equity 3 year olds. Thankfully this had been minimized by increases in the base rate. The early childhood community were divided about the model as discussions on the egroup revealed. It has long been a ploy to keep the sector fragmented and the new model certainly continued this process. Additional hours spent trolling through websites accessing research which informed our decisions were conducted outside of school and working hours, while juggling a full teaching load and 'negotiating' the changes to supporting children with additional needs funding from Samaritans (SCAN)

Another question that kept popping up was: Where were all these 4 year olds to come from? For some towns the children didn't exist!' We have delivered this message to the government in submissions that it sought about the model. As a response, Community Childcare and later government advised centres to pitch their marketing to attract new families. The work again fell back on us. As our online group discussions revealed, centre directors worked diligently to produce the outcomes desired by the state government, cognizant that the New South Wales government has underspent on early childhood education despite many advocacy campaigns to raise the issue in the public arena. Moreover, in 2016, the department required us to report twice a year!

In August 2016 the media broke what we had all suspected: the NSW Government had underspent on early childhood education over the last 5 years by $\$ 365$ million (See Figure 3). This caused a great deal of angst across the sector which was communicated on the online forum in passionate words creating new divisions. We knew this underspending was occurring but as alluded to earlier, was unable to prove despite our advocacy efforts. With wage parity for early childhood teachers and educators always put on bold due to lack of funds, the sector was less than happy Macfarlane \& Lewis, 2012, http:/ / www.bigsteps.org.au ). Staff in centres knew that ultimately families would bear the cost of any wage increases. Therefore, they bore the loss in wages and superannuation squarely on their shoulders. 
Zsuzsa Millei and Jannelle Gallagher Ad-hoc numbers forming provision and policy: round and round of universal access in an Australian preschool Early Child Development and Care http://dx.doi.org/10.1080/03004430.2017.1289926

\section{Many teachers, who have now retired, dedicated their time and sacrificed their own financial security to prop up early childhood education in NSW, while the state governments gathered their coffers.}

The Hon. WALT SECORD: Okay. I have the budget papers in front of me. It is actually in the budget papers. It shows that since 2011 to 2016 , the department underspent $\$ 365$ million in the area of early childhood education. Mrs Williams, with a massive waiting list of parents needing affordable early childhood education, how can you underspend $\$ 365$ million in five years? Can you please explain that?

Ms LESLIE WILLIAMS: Certainly. First, the difference is between the budget allocation and the spend. For the past year, it was only $\$ 15.2$ million, but for the previous years that you are referring to, that is largely as a result of the uncertainty from Commonwealth funding. I am sure you are aware that we have funding contributed to early childhood education both by the State and the Commonwealth. The New South Wales Government primarily funds community preschools. We have some 750 across the State. We fund them through the preschool funding model.

The Hon. WALT SECORD: Acting Chair, could I return to the question? The question is: How did you fail to spend $\$ 365$ million?

Ms LESLIE WILLIAMS: As I said, the difference between the budget allocation and the spend is largely due to the uncertainty of funds that we received from the Commonwealth. In fact, the issue is that the funding we received from the Commonwealth is for short terms. You will know from the hearing last year that I explained that the first national partnership agreement with the Commonwealth was for one year. The next agreement was for two years, which will conclude next year. The problem is, as I said, that it is short term. Often we receive funding late because the funding from the Commonwealth is based on performance indicators so it is not just a single amount that is given to us at the beginning of every year.

Figure 3. Unspent Funds - General Purpose Standing Committee No 3. Monday, 29 August 2016 Examination of proposed expenditure for the portfolio areas Early childhood education / Aboriginal affairs - Uncorrected proof (p. 2)

https://www.parliament.nsw.gov.au/committees/DBAssets/InquiryOther/Transcript/10125/Early\%20C hildhood $\% 20$ Education $\% 20$ Aboriginal $\% 20$ Affairs $\% 20$.pdf

Calculating enabled the preschool to develop a new model and budget that ensured not only the survival of the preschool but also tried to maximize the income possible to reduce the overall fees for families. This situation changed group compositions and the pedagogy required to care for and teach children. Calculations also required extra time and large efforts of staff who volunteered in order to create some security for the future, but in effect also fulfilling the government's agenda on universal access. Penalties and losses turned into more energies and requests for government help, but to get to a solution was passed back to preschools. The preschool needed 4 year olds that were hard to find both because of dropping birth rates, still considerably high fees, due to parents' decision to not enrol their children and inability of some families to actually get to the preschool with their children.

Technology also controlled work and the unknown terminology and criteria under which circumstances of children had to be coded also required extra time. The government set deadlines only could be reached through unusual and unpaid work hours. Through technology data were generated towards universal access, but in order to input data 
Zsuzsa Millei and Jannelle Gallagher Ad-hoc numbers forming provision and policy: round and round of universal access in an Australian preschool Early Child Development and Care http://dx.doi.org/10.1080/03004430.2017.1289926

technology needed to function. Its failure digested extra human labour, time and revenues. However, technological advances and the capitalisation on children's lives, such as in the form of creating links to SEIFA measures or attaching numbers to particular children's enrolment, helped to new forms of quantification.

Old and new lines of power have also strengthened. The government encouraged educators to work for longer days than their counterparts in schools. It also assumed that they will continue with irregular and unpaid hours in teaching, administration and campaigning for more enrolments. Staff sacrificed willingly their own free time and time spent with their families. This has meant that the sector continued on its historical path and exploited the willingness of colleagues to do the best for children and families without due financial and professional recognition (Macfarlaine \& Lewis, 2012).

Those centres known as 'early uptakers' were encouraged to tell their stories to promote their success in modelling and budgeting (together with streamlined enrolments) via professional videos recorded and distributed by the government to other professionals. After completing the adding of our data online, I was contacted by the Department of Education. After several calls to clarify and extend on my responses about the ways in which we have managed to increase participation in 600 hours and targeted enrolments, we were invited to make a video sharing our success story. We agreed, but were unsure of when this would occur. However, this happened very expediently and without hesitation we complied mindful of promoting the great work we do at the preschool as well beyond what they expected us to report on.

In November 2015, NSW preschools failed to reach the government's target of $95 \%$ of children attending 600 hours of preschool education again. This provoked the NSW Government to offer even more generous incentives; launching the 'Community Preschools 600 hour's Incentive' (Incentive). The new Incentive stated that if services increased their participation rates of 4 year olds attending 600 hours by $5 \%$ - $15 \%$, they would attract an equal percentage rate on their base funding ${ }^{14}$. It seems value created another layer of value and directors were encouraged to do more creative modelling through videos.

\footnotetext{
14 A child is eligible for Base Funding if the child turns 4 before July 31 the preschool year or is an equity 2 year old child (disadvantaged background or Indigenous).
} 
Zsuzsa Millei and Jannelle Gallagher Ad-hoc numbers forming provision and policy: round and round of universal access in an Australian preschool Early Child Development and Care http://dx.doi.org/10.1080/03004430.2017.1289926

What becomes visible through these circles and reactive policy making (incorporating feedback as new initiatives and incentives), is that the sector was the united actor that has struggled through the configuration of the possibility for and the realization of universal access. Preschools have moved beyond the task of policy enacting and informing, and became policy forming (Grek \& Ozga, 2010). While the government initially only laid out its initiatives and trajectories in provisional numbers, the sector has worked through possible strategies of how universal access might just become possible. The government followed and supported the developing models rather than playing a proactive role in finding solutions. For example, to help make maintain and create connections between directors and staff working in preschools, the government set up a new forum called the Start Strong Ehub mirroring the already existing egroup. The Government also invested in a parent awareness campaign called 'It makes you think' ${ }^{15}$ to help preschools to promote the importance of preschool education for families following already formalized processes in preschools. The video further promoted the strategies that preschool directors assembled towards the achievement of universal access. The sector became policy forming. However, this perhaps remained hidden from view since the processes and practices that formalized often countered the sector's advocacy efforts to improve their work conditions and every child's rights to quality early education (even if included in the Early Years Learning Framework (ADGEEWR, 2009)). The role of forming policy also comes with spaces where these hopes might be realised in particular strategies and modelling.

However, as we became less focused on creating a viable model, negotiations with staff began marrying our philosophy and practice to ensure we were proposing a quality educational program for the children and their families. Our own families also deserved consideration, since they were the ones suffering in our absence from home and decreased family budgets due to free labour. Therefore, it became imperative that all staff had input and felt that their expressed thoughts and concerns regarding the fast changes happening during the past years were addressed.

In general, we also felt that preschool staff still suffered a general lack of respect from the government, both

\footnotetext{
15 http://www.dec.nsw.gov.au/what-we-offer/regulation-and-accreditation/early-childhood-educationcare/funding/start-strong/info-for-parents
} 
Zsuzsa Millei and Jannelle Gallagher Ad-hoc numbers forming provision and policy: round and round of universal access in an Australian preschool Early Child Development and Care http://dx.doi.org/10.1080/03004430.2017.1289926

as professionals having the same qualifications as teachers ${ }^{16}$ working in schools and for the expert work they do to educate and care for children. If this was not the case, then why would we be asked to increase the hours of provision for young children when at school they are attending for 6 bours only (9am-3pm)? Would school teachers change their hours to accommodate the government whims? Would they be asked to do so and would not their advocacy organizations be heard and listened to? In addition, we often thought, what will happen when the National Partnership expires in June 2018? How can we plan in longer term to ensure our viability and stability in this rapidly changing and insecure environment, especially without due payments from the government to support the provision of quality ECEC and salaries that acknowledge the quality of work we do and commitment we make? Why school funding is ensured for each year and why ECEC funding needs to be constantly negotiated if at all we receive money?

Creative calculations came with heavy moral and ethical considerations, such as how one can use policy initiatives to form models that actually has something to do with families and children's lives, professional acknowledgement and the provision of quality early learning. These were especially complex questions in a context where the sector became divided, professional solidarity has weakened, families support became vital, advocacy work became quieter on work conditions and educators' employment became even more precarious based on fluctuating enrolments and dependent on creative calculations to keep preschools alive. Despite these dilemmas defining the general mood, a great progress has been made, especially since 2013, on universal access in NSW. The sector is very proud of this. It is however also important to add that this achievement was mostly due to the competency and sacrifices of directors and educators in a context where respect and recognition from the state government was hard to come by.

\section{Concluding thoughts}

The personal story of universal access is about a capable, experienced and reflective director who led her preschool through renewed policy initiatives, reporting, terminologies, technology, long and hard fought negotiations with staff, families and

\footnotetext{
16 Preschool teachers have a 4-year university degree. With this degree, in most of the cases, they are also qualified to teach in primary school too. There is a long standing action for pay parity coordinated by the Independent Education Union of Australia. See also news here: http://www.dailytelegraph.com.au/news/nsw/early-childhood-teachers-push-for-pay-parity-with-primaryschool-teachers/news-story/38ffedb1c9055b7437ed54b17d8e7f4e
} 
Zsuzsa Millei and Jannelle Gallagher Ad-hoc numbers forming provision and policy: round and round of universal access in an Australian preschool Early Child Development and Care http://dx.doi.org/10.1080/03004430.2017.1289926

professional colleagues to contribute to increase enrolment and in effect to help realise universal access. The several ethical dilemmas that emerged through this work often placed her in ambivalent positions, such as between resisting the constant demands for unpaid work or fulfilling reporting deadlines, realising the requests of families of 3 year olds for preschool education or keeping the preschool viable, restructuring preschool provision or keeping staff and the sector's interests in mind for recognition and pay parity and equality in work conditions, accepting the government's recognition for her great work on optimizing the budget or instead making a statement on the continued lack of recognition, underfunding and exploitation of the sector's professionals. Relying on her ethics, moral judgements, and reflections, navigating this field proved to be very challenging for her and was wrought with controversies. Clear cut decisions often appeared in new light seeing how they have materialised in the everyday running of the preschool and brought up new questions and renewed ethical dilemmas.

Universal access to quality early childhood education circulates in global discourses as a commonly agreed greater good that benefits families, children and national economies (Millei \& Joronen, 2016; Millei, 2015). In this story the road to universal access has brought many challenges to policy makers, bureaucrats, organisations, preschools, professionals and families. While children's rights to quality ECEC is a common good that the national curriculum for the early years also upholds, its materialisation through a data and evidence governed policy circle seems falling far from the ideal that the field keeps dreaming about, the right to early education for every child (Macfarlaine \& Lewis, 2012). It seems the realisation of universal access in NSW demanded far more free labour, compromise and sacrifice on behalf of everyday ECEC actors that perhaps the field has ever anticipated. It also further entrenched the power lines along the real or imagined fragmentation of the sector (Bown \& Sumsion, 2016). It made preschools policy informing and forming through professionals' creative calculations, strategizing and modelling and the constant submissions to government. Therefore, the state government's initiatives on the path towards universal access - more precisely using provisional numbers sugar-coated in some extra funding to ignite responses from the sector - represent more of a political exercise than commitment to universal access. This is also visible in the lack of concern to alleviate the many problems plaguing NSW ECEC. Shorter term and last minute commitments from the Commonwealth government add to the complexity of the situation by challenging the state government 
Zsuzsa Millei and Jannelle Gallagher Ad-hoc numbers forming provision and policy: round and round of universal access in an Australian preschool Early Child Development and Care http://dx.doi.org/10.1080/03004430.2017.1289926

to act in somewhat ad hoc ways that in turn challenges its ability to distribute funding channelled through their budget ${ }^{17}$. This in turn makes preschools' modelling painstakingly difficult, budgets highly volatile ${ }^{18}$ hence preschools' existence precarious.

In this paper we shed some lights on formalizing processes that use provisional, temporary or emergent practices that at times become stabilized, fixed and destabilizing depending upon the social conditions of their production (Lampland, 2010). Therefore, attending to the procedures, ethical dilemmas, controversies and ambiguities whereby new or ephemeral practices are introduced, mastered or stymied as part of policy initiatives is necessary to find potent ways to press agendas in the new context where policy informing and forming became a part of the work preschools do. While the realisation of this complex work further burdens the anyway 'tired' sector, this new era also brings untapped and exciting potentials for preschools' renewed activism.

\section{References}

AGDEEWR (Australian Government Department of Education, Employment and Workplace Relations) (2009) Belonging, Being \& Becoming: The Early Years Learning Framework for Australia.

https://docs.education.gov.au/system/files/doc/other/belonging being and becoming the_early_years_learning_framework_for_australia.pdf

Beer, D. (2015) Productive measures: Culture and measurement in the context of everyday neoliberalism. Big Data \& Society, 1, 1-12.

Bown, K. \& Sumsion, J. (2016) Generating visionary policy for early childhood education and care: Politicians' and early childhood sector advocate/activists' perspectives Contemporary Issues in Early Childhood, 17(2) 192-209.

Brennan, B. (2012) Review of NSW Government Funding for Early Childhood Education. NSW Government.

Bullough, R.V. \& Pinnegar, S. (2001) Guidelines for Quality in Autobiographical Forms of Self-Study Research. Educational Researcher, 30(3) 13-21

Callon, M. \& F. Muniesa (2005) Peripheral Vision: Economic Markets as Calculative Collective Devices. Organization Studies, 26(8) 1229-1250.

\footnotetext{
${ }^{17}$ See notes from the General Purpose Standing Committee discussing the issue of Commonwealth moneys unspent by state administration while preschools were struggling with funds https://www.parliament.nsw.gov.au/committees/DBAssets/InquiryOther/Transcript/10125/Early $\% 20 \mathrm{C}$ hildhood $\% 20$ Education $\% 20$ Aboriginal $\% 20$ Affairs $\% 20$.pdf

18 The Commonwealth government entered into the policy scene of ECEC with the 2009 National Partnership. This role is however limited overseeing and partly subsidising ECEC in order to reach universal access. Historically, the provision and regulation of ECEC was the responsibility of states and territories, which they have kept after 2009. So the Commonwealth funding is channelled through the state and territory governments.
} 
Zsuzsa Millei and Jannelle Gallagher Ad-hoc numbers forming provision and policy: round and round of universal access in an Australian preschool Early Child Development and Care http://dx.doi.org/10.1080/03004430.2017.1289926

Campbell-Barr, V. \& Nygård, M. (2014) Losing Sight of the Child? Human Capital Theory and its Role for Early Childhood Education and Care Policies in Finland and England since the Mid-1990s. Contemporary Issues in Early Childhood, 15(4) 346-359. Cohen, B.J. \& Korintus, M. (2016) Making connections: reflections on over three decades of EU initiatives in Early Childhood Education and Care (ECEC). Early Years, http://dx.doi.org/10.1080/09575146.2016.1181050

Council of Australian Governments (2008) National Partnership Agreement on the Quality Agenda for Early Childhood Education and Care. Canberra.

Preschool Education in Australia. Policy Brief.

http://research.acer.edu.au/policy_briefs/1/

Grek, S and Ozga, J (2010) Re-inventing public education. The new role of knowledge in education policy making. Public Policy and Administration, 25(3): 271-288.

Lampland, M. (2010) False numbers as formalizing practices. Social Studies of Science, 40(3) 377-404.

Macfarlaine, K. \& Lewis, P. (2012) United We Stand: seeking cohesive action in early childhood education and care. Contemporary Issues in Early Childhood 13(1) 63-73. Millei, Z. (2015) Governing the Brain: New narratives of human capital in early childhood education. (pp. 47-70) In T. Lightfoot \& R. Peach (Eds) Questioning the Discourses of Human Capital in Early Childhood Education: Reconceptualizing Theory, Policy and Practice. New York: Palgrave

Millei Z. \& Jones, A. (2014) Australian early childhood education and care policy and the (re)production of global imaginary. International Journal of Early Childhood. 46(1) 63-79.

Millei, Z. \& Joronen, M. (2016) The (bio)politicization of neuroscience in Australian early years policies: Fostering brain-resources as human capital. Journal of Education Policy, 31(4) 389-404.

Mills, C. W. (1959). The sociological imagination. New York: Oxford University Press. Osgood, J. (2009) Childcare workforce reform in England and 'the early years professional': a critical discourse analysis, Journal of Education Policy, 24(6), 733-751 Porter, T. (1995) Trust in Numbers: The Pursuit of Objectivity in Science and Public Life Princeton: Princeton University Press.

Productivity Commission (2016) National Education Evidence Base, Draft Report, Canberra Roberts-Holmes, G. (2014) The 'datafication' of early years pedagogy: 'if the teaching is good, the data should be good and if there's bad teaching, there is bad data'. Journal of Education Policy, 30(3) 302-315.

Warren, S. (2017) Struggling for visibility in higher education: caught between neoliberalism 'out there' and 'in here' - an autoethnographic account. Journal of Education Policy, 32(2) 127-140.

White, L. (2011) The Internationalization of Early Childhood Education and Care Issues: Framing Gender Justice and Child Well-being. Governance 24(2) 285-309. 